\title{
IDENTIFIKASI PARTISIPASI MASYARAKAT DALAM PENGEMBANGAN OBJEK WISATA DI DESA SAMBANGAN, KECAMATAN SUKASADA KABUPATEN BULELENG
}

\author{
Putu Rinda Rismayanti, Luh Masdarini, Ni Made Suriani \\ Program Studi Pendidikan Kesejahteraan Keluarga, Fakultas Teknik \\ danKejuruan, Universitas Pendidikan Ganesha, \\ Singaraja, Indonesia \\ Email: rismayantirinda@gmail.com masdarini@undiksha.ac.id \\ made.suriani@undiksha.ac.id
}

\begin{abstract}
Abstrak
Penelitian ini bertujuan untuk mendeskripsikan potensi wisata dan partisipasi masyarakat Desa Sambangan dalam pengembangan objek wisata, baik objek wisata alam maupun buatan. Partisipasi tersebut meliputi partisipasi dalam hal perencanaan pengembangan objek wisata, partisipasi dalam hal pelaksanaan pengembangan objek wisata dan partisipasi dalam hal pengawasan pengembangan objek wisata. Teknik pemilihan informan dengan menggunakan snowball sampling dengan mengelompokan masyarakat dalam 3 kategori menurut teori Pitirim A. Sorokin, yaitu upper class, middle class dan lower class. Teknik pengumpulan data dengan metode (1) observasi (2) wawancara dan (3) dokumentasi. Sedangkan instrumen penelitian yang digunakan yaitu (1) lembar observasi dan (2) pedoman wawancara. Analisis data menggunakan teknik deskriptif kualitatif. Hasil penelitian ini menunjukan bahwa di Desa Sambangan terdapat berbagai potensi wisata yang apabila dikembangkan dapat menjadi objek wisata andalan. Potensi alam berupa air terjun dan hutan desa, potensi wisata buatan berupa palowan hidroponik dan kolam renang serta partisipasi masyarakat dalam hal perencanaan pengembangan objek wisata termasuk dalam kategori interaktif, dalam hal pelaksanaan pengembangan objek wisata termasuk dalam kategori manipulatif dan dalam hal pengawasan pengembangan objek wisata termasuk dalam partisipasi inisiatif.
\end{abstract}

Kata kunci: Identifikasi, partisipasi masyarakat, objek wisata, Desa Sambangan.

\begin{abstract}
This study aimed to describe the tourism potential and the participation of Sambangan Village community in the development of tourism objects, both natural and artificial tourism objects. The participation included the participation in planning the development of the tourism objects, participation in implementing the development of the tourism objects, and participation in controlling the development of the tourism objects. In selecting the informants, the technique used in this study was snowball sampling by grouping the people in 3 categories based on Pitrim A. Sorokin's theory, such as upper class, middle class, and lower class. The methods used in collecting the data were (1) Observation, (2) Interviews, and (3) Documentation. Meanwhile, the instruments used were (1) Observation sheets, and (2) Interview Guidelines. The data analysis used descriptive qualitative techniques. The results of this study showed that in Sambangan Village, there are variety of tourism potentials, in which if those tourism objects were developed, they could be mainstay tourist attractions. The potential of the natural tourism objects, such as waterfalls and village forests, meanwhile the artificial tourism objects, such as hydroponic palaces and swimming
\end{abstract}


pools as well as the community participation in planning the development of the tourism objects was categorized in interactive category, in terms of implementing tourism development was categorized in manipulative category and in terms of controlling the development of the tourism objects was categorized in initiative category.

Keywords: identification, community participation, tourism objects, Sambangan Village

\section{PENDAHULUAN}

Buleleng merupakan salah satu kabupaten di Provinisi Bali yang letaknya di belahan utara pulau Bali. Memiliki luas wilayah 1.365, $88 \mathrm{Km} 2$ atau $24,25 \%$ dari luas Provinsi, dan secara administratif terdiri dari 9 Kecamatan, 129 Desa, 19 Kelurahan, dan 169 Desa Adat.

Perkembangan pariwisata di
Kabupaten Buleleng mengalami
kemajuan yang pesat sejak
pemerintah pusat mengambil
langkah strategis dengan
menyerahkan kewenangan
mengelola sektor pariwisata kepada
pemerintah Kabupaten/Kota demi
memudahkan pengembangan
pariwisata nasional. Salah satu
langkah yang diambil oleh
pemerintah Kabupaten Buleleng
terkait hal tersebut adalah dengan
mengeluarkan surat keputusan
tentang pembentukan Desa wisata.
Nuryanti (1993), mendefinisikan
pariwisata pedesaan sebagai salah
satu bentuk integrasi antara atraksi,
akomodasi dan fasilitas pendukung
yang disajikan dalam suatu struktur
kehidupan masyarakat yang
menyatu dengan tata cara dan tradisi
yang berlaku.

Berdasarkan Surat keputusan Bupati Buleleng No. 430/927/HK/2015, Desa Sambangan ditetapkan sebagai salah satu desa wisata di Kabupaten Buleleng. Terletak di Kecamatan Sukasada, kurang lebih $6 \mathrm{~km}$ dari pusat Kota Singaraja, Desa sambangan memiliki daya Tarik wisata yang luar biasa. Terdapat berbagai potensi wisata baik alam maupun buatan yang hingga saat ini beberapa sudah dikembangkan menjadi objek wisata andalan di Kabupaten Buleleng.

Dalam usaha meningkatan pelayanan dan mutu dari objek-objek wisata di desa sambangan, tentu saja harus ada kerjasama dari berbagai pihak. Disinilah partisipasi masyarakat lokal sangat diperlukan dalam hal menjaga keberlanjutan keberadaan objek wisata tersebut. Menurut Adisasmita (2006, hal: 34) Partisipasi merupakan peran serta masayrakat dalam pembangunaan suatu kawasan pedesaan, dimana bersedia ikut serta dalam pembangunan suatu proyek. Dengan pelibatan masyarakat secara aktif diharapkan akan memberikan dampak yang baik bagi pemerintah dan masyarakat itu sendiri. Namun pada kenyataannya masyarakat yang berkecimpung dalam dunia pariwisata masih sedikit. Hal ini dibuktikan dengan melihat data mata pencaharian pokok dan mata pencaharian penduduk pada sektor jasa dalam profile Desa Sambangan tahun 2018. Dari total 5.366 jumlah penduduk, dengan jumlah penduduk usia produktif sebanyak 2.953 jiwa, sebagian besar bekerja sebagai buruh tani yaitu sejumlah 755 orang. Sedangkan pada sektor jasa, masyarakat pemilik usaha jasa transportasi, hiburan pariwisata, hotel dan penginapan hanya sejumlah 18 orang. Bahkan tercatat terdapat 392 orang usia produktif yang tidak/belum mempunyai pekerjaan tetap, padahal sektor pariwisata berpotensi menyediakan lapangan pekerjaan utamanya utuk 
generasi muda. Apalagi Desa Sambangan sudah memiliki potensi wisata alam dan buatan yang khas.

Selain itu mengacu pada hasil penelitian yang dilakukan oleh Gede Sudirtha dkk (2019) yang berjudul International Journal of Social Sciences and Humanities, dari aspek pengembangan desa wisata di Desa Sambangan belum secara optimal memanfaatkan sumber daya alam atau sumber daya lainnya sebagai produk desa wisata yang layak dan dari hasil analisis yang dilakukan, pengembangan produk desa wisata ini membutuhkan model manajemen yang menggabungkan unsur-unsur sumber daya alam di desa dengan kearifan lokal Bali yang mendasari kehidupan dan perilaku masyarakat Bali secara umum dan membutuhkan sentuhan inovasi berbasis teknologi.

Berdasarkan urain tersebut maka penulis merasa tertarik untuk melakukan penelitian terkait potensi wisata dan partisipasi masyarakat lokal dalam pengembangan objek wisata di Desa Sambangan, Kecamatan Sukasada, Kabupaten Buleleng.

\section{METODE PENELITIAN}

Dalam penelitian ini digunakan pendekatan kualitatif yaitu metode penelitian yang digunakan pada kondisi objek yang alamiah, dimana peneliti adalah sebagai instrument kunci. Pengambilan informan sumber data dilakukan dengan snowball sampling dimana pengambilan sampel berdasarkan wawancara atau korespondensi. Metode ini dilakukan dengan meminta informasi dari sampel pertama untuk mendapatkan sampel berikutnya hingga informasi yang didapat dirasa cukup. Teknik pengumpulan data dengan triangulasi (gabungan), analisis data bersifat induktif/kualitatif dan hasil penelitian lebih menekankan makna daripada generalisasi (Sugiyono: 2007, 15). Pendekatan ini digunakan untuk menjabarkan potensi wisata yang ada di Desa Sambangan dan bagaimana partisipasi masyarakat dalam hal perencanaan, pelaksanaan dan pengawasan pengembangan objek wisata yang ada di Desa Sambangan.

Jenis penelitian yang digunakan adalah deskriptif, metode penelitian deskriptif merupakan suatu metode yang digunakan untuk menggambarkan atau menganalisis suatu hasil penelitian namun tidak digunakan untuk membuat kesimpulan yang lebih luas (Sugiyono: 2005, 160).

Penelitian ini mengambil tempat di Desa Sambangan, Kecamatan Sukasada, Kabupaten Buleleng yang berdasarkan Surat Keputusan Bupati Buleleng Nomor 430/927/HK/2015 sudah ditetapkan sebagai Desa Wisata. Waktu pelaksanaan penelitian dan pengambilan data mulai dilakukan pada Kamis, 23 Mei 2019 sampai Februari 2020. Penelitian ini menggunakan dua sumber data, yaitu (1) Data Primer merupakan data yang diperoleh secara langsung dari hasil wawancara, observasi dan dokumentasi. Sumber data primer ini diperoleh dari masyarakat Desa Sambangan yang telah dibedakan menurut kelas sosialnya berdasrkan teori Pitirim A. Sorokin. Kelas sosial tinggi (upper class) yaitu: pejabat dalam hal ini peneliti menjadikan Kepala Desa Sambangan sebagai narasumber. Kelas sosial menengah (midle class) yaitu: tokoh penggerak pariwisata, pengusaha kecil dan menengah dalam hal ini narasumber yang digunakan adalah anggota POKDARWIS dan pemilik usaha yang terkait parwisiata seperti toko souvenir, warung makan dan akomodasi di Desa Sambangan. 
Serta kelas sosial rendah (lower class) yaitu: buruh dan petani. (2) Data Sekunder merupakan data yang diperoleh dari pihak lain yang tidak termasuk kedalam kelas sosial masyarakat namun memiliki kaitan dengan penelitian yang digunakan. Dalam hal ini peneliti memperoleh data berupa dokumentasi kegiatan kepariwisataan dari pihak BUMDES Sambangan.

Variabel penelitian ini yaitu partisipasi masyarakat dalam pengembangan objek wisata alam dan buatan di Desa Sambangan. Definisi operasional variabel dalam penlitian ini akan mengidentifikasi keikutsertaan masyarakat dalam melaksanakan suatu program, terbagi menjadi tiga tahap yaitu perencanaan, yang merupakan suatu proses yang menyangkut upaya untuk mengantisipasi kemungkinan di masa yang akan datang dan penentuan strategi. Tahap pelaksanaan di sektor formal meliputi realisasi program-program yang telah direncanakan dan sektor informal meliputi usaha sendiri yang pekerjanya jarang terikat aturan hukum dan tahap pengawasan untuk memastikan seluruh rangkaian kegiatan berjalan baik.

Masyarakat dapat diartikan sebagai suatu jaringan hubunganhubungan antar entitas-entitas, yang interdependen atau saling tergantung satu sama lain. Masyarakat yang dimaksud disini dibedakan berdasarkan kelas sosialnya, yaitu kelas sosial tinggi (upper class) contohnya: pejabat, dan pengusaha, kelas sosial menengah (middle class) contohnya: guru, pegawai negeri, pengusaha kecil dan menengah, serta kelas sosial rendah (lower class) contohnya: buruh dan petani

Objek wsiata merupakan segala sesuatu yang ada di daerah tujuan wisata yang merupakan daya tarik sehingga orang-orang berminat untuk mengunjungi tempat tersebut.
Metode pengumpulan data dilakukan dengan wawancara, observasi dan dokumentasi. Teknik analisis data dalam penelitian ini adalah deskriptif kualitatif. Yang terbagi menjadi tiga komponen analisis menurut Miles dan Huberman yang dikutip oleh Sugiyono (2011:246) yaitu reduksi data, penyajian data dan penarikan kesimpulan.

\section{HASIL DAN PEMBAHASAN}

\section{HASIL}

Desa sambangan memiliki potensi wisata yang beragam, Sebagai Desa yang terletak cukup jauh dari hiruk pikuk perkotaan, Desa Sambangan memiliki alam yang masih sangat asri dan indah sehingga menarik untuk dikunjungi. Terdapat berbagai potensi wisata alam di Desa ini, diantaranya adalah Air terjun. Sebagai Desa yang terletak di daerah dataran tinggi, banyak sungai-sungai yang mengalir di Desa Sambangan, dan karena proses geologis maka terbentuklah beberapa air terjun yang memiliki keindahan luar biasa sehingga berpotensi untuk dijadikan ojek wisata. Adapun air terjun tersebut adalah Air terjun Aling-Aling, Air Terjun Kroya, Air Terjun Kembar, dan Air terjun Pucuk yang hingga saat ini masih ramai dikunjungi wisatwaan dan telah dikelola dengan baik. Adapun tiga air terjun lain seperti Cemara, Canging dan Dedari letaknya masih cukup sulit dijangkau dan belum terdapat fasilitas yang memadai karena terletak di tengah hutan. Hutan Desa Sambangan juga memiliki potensi wisata yang cukup menjanjikan apabila dikelola dengan baik. terdapat beranekaragam hayati dan daya Tarik tersembunyi dari ketiga air terjun.

Desa Sambangan telah membentuk Lembaga Pengelola Hutan Desa (LPHD), berkolaborasi 
dengan POKDARWIS Tunjung Mekar, memiliki program untuk mengembangkan hutan Desa Sambangan sebagai objek wisata. Ada beberapa program yang ingin dikembangkan di hutan desa, diantaranya adalah pembentukan paket wisata agro, yang diharapkan dapat dikelola langsung oleh masyarakat desa sambangan, memaksimalkan potensi air terjun terutama yang belum terjamah seperti air terjun gangga, serta mengembangkan atraksi wisata berupa rock climbing, survival camp dan mini rafting. Kemudian untuk aktivitas wisata yang telah berjalan seperti camping dan trekking, kedepannya akan terus dikembangkan baik dari segi SDM (Sumber Daya Manusia) maupun sarana prasarana.

Selain potensi wisata alam, terdapat pula potensi wisata buatan. Potensi wisata ini merupakan hasil karya cipta manusia yang dapat menarik minat wisatawan. Adapun potensi tersebut adalah (1) Palowan Hidroponik Sambangan yang merupakan sebuah kawasan budidaya tanaman dengan media air. (2) Kolam Renang Amour Legawa dan (3) Alam Sambangan.

Selain diperlukannya potensi berupa potensi alam dan potensi buatan, potensi sumber daya manusia dalam pengelolaan pariwisata juga sangat penting. Berdasrkan profile Desa Sambangan tahun 2018, dari total 5.366 jumlah penduduk yang 2.953 diantarnya berusia produktif jika dilihat dari tingkat pendidikan dan kualitas angkatan kerja, terdapat 572 jiwa yang tamat SMA sederajat dan 1.464 jiwa yang tamat perguruan tinggi. Hal ini menunjukan bahwa masyarakat di Desa Sambangan sudah memiliki sumber daya manusia dengan pengetahuan yang baik untuk mengelola potensi wisata alam dan buatan yang ada. Dalam pengelolaan objek wisata tentunya tidak dapat terlepas dari syarat-syarat pengembangan suatu kawasan wisata, yaitu what to see, what to do, what to buy, what to do arrived dan what to stay. Di Desa Sambangan unsur yang masih perlu diperhatikan adalah aksesbilitas menuju ke beberapa kawasan wisata, terutama wisata alam air terjun. Pengadaan aktivitas wisata budaya dan toko cendera mata juga patut dipertimbangkan agar kunjungan wisatawan terus meningkat.

Bentuk partisipasi masyarakat Desa Sambangan mulai dari awal perencanaan, pelaksanaan hingga pengawasan dalam pengembangan objek wisata yang ada di Desa, baik objek wisata alam maupun buatan. Adapun bentuk partisipasi dalam hal perencanaan antara lain keikutsertaan masyarakat dalam musyawarah desa, mengikuti sosialisasi kegiatan kepariwisataan tingkat regional, nasional maupun internasional, dan rapat rutin yang dilaksanakan oleh kelompokkelompok dibidang pariwisata. Dalam hal pelaksanaan pengembangan objek wisata, partisipasi masyarakat Desa Sambangan terbagi menjadi partisipasi dalam sektor formal dan informal. Sektor formal yang meliputi keikutsertaan dalam kegiatan BINTEK dan pelatihan yang dilaksanakan oleh pihak internal maupun eksternal Desa serta pelaksanaan kegiatan gotong royong yang dilaksanakan secara berkala dan terjadwal. Dalam sektor informal bentuk partisipasi masyarakat dapat dilihat dari kepemilikian akomodasi pondok wisata Wavi Leisures, karyawan Kunang-Kunang, kepemilikan toko cendera mata, warung makan Aling-Aling Bambu, warung makan di Palowan Hidroponik dan penyediaan lahan perkebunan dan persawahan untuk aktivitas wisata. Sedangkan dalam hal pengawasan pengembangan objek wisata masyarakat desa 
Jurnal Bosaparis: Pendidikan Kesejahteraan Keluarga

Volume 11, Nomor 2, Juli 2020

$\begin{aligned} & \text { sambangan berpartisipasi } \\ & \text { mengawasi } \\ & \text { penerapan sapta } \\ & \text { pesona, membuat laporan }\end{aligned}$
pertanggungjawaban, mengikuti
MUSDES dan pengawasan terhadap
kualitas SDM dibidang pariwisata.

\section{PEMBAHASAN}

Sesuai dengan teori yang disampaikan oleh Maryani (1991:11) suatu objek wisata dapat menarik untuk dikunjungi oleh wisatawan harus memenuhi syarat-syarat untuk pengembangan daerahnya. syaratsyarat tersebut sudah terpenuhi dengan baik di Desa Wisata Sambangan. Terdapat keindahan yang bisa dilihat, terdapat aktivitas seperti slidding, jumping, foto shooting dan canyonning yang dapat dilakukan, terdapat berbagai jenis akomodasi yang dapat ditinggali, restoran dan rumah makan untuk pemenuhan kebutuhan serta aksesbilitas untuk mencapai objek wisata. Adapaun yang perlu diperhatikan adalah aksesbiltas dan ketersediaan toko cendera mata di sekitar kawasan wisata alam dan buatan.

Menurut teori yang disampaikan Tjokrowinoto dkk dalam Nandi (2008: 4), bahwa figur atau sosok sumber daya manusia pada abad 21 adalah manusia-manusia yang memiliki wawasan pengetahuan (knowledge), ketrampilan (skill), dan sikap atau perilaku (attitude) yang sesuai dan mampu menunjang pencapaian dan sasaran. Di Desa Sambangan sumber daya manusia yang ada apabila dikaitkan dengan pengembangan pariwisata sebagian besar sudah memiliki wawasan pengetahuan, terbukti dengan tingkat pendidikan yang relatif tinggi. Dalam hal keterampilan di bidang kepemanduan wisata sumber daya manusia Desa Sambangan sudah dibekali dengan ilmu dari berbagai pelatihan dan sosialisasi, hanya saja masyarakat yang dilatih masih terbatas pada yang ikut bergabung dalam POKDARWIS

Bentuk-bentuk partisipasi masyarakat dalam pengembangan objek wisata di Desa Sambangan sudah terbilang aktif, masyarakat dari semua golongan telah diikutsertakan dalam proses pengembangan. Jika dilihat dari teori yang disampaikan oleh Oktami Dewi A. A. P, (2013) partisipasi dalam hal perencanaan pengembangan objek wisata di Desa Sambangan termasuk kedalam partisipasi interaktif. Partisipasi dalam hal pelaksanaan pengembangan objek wisata termasuk kedalam partisipasi manipulatif, serta dalam hal pengawasan termasuk kategori partisipasi inisiatif.

\section{SIMPULAN DAN SARAN}

\section{SIMPULAN}

Desa Sambangan memiliki potensi wisata alam dan buatan yang beragam, baik yang sudah dikembangkan dengan baik seperti potensi alam berupa air terjun Kroya, Aling-Aling, Kembar dan Pucuk maupun yang masih dalam tahap pengembangan dan pemaksimalan potensi seperti air terjun Cemara, Dedari, Canging dan kawasan hutan dengan berbagai potensi wisatanya. Potensi wisata buatan yang sudah berkembang pesat yaitu kolam renang, wisata hidroponik dan alam sambangan serta yang masih dalam tahap perencanaan pengembangan seperti sanggar seni budaya. Untuk potensi sumber daya manusia terkait pariwisata, Desa Sambangan sudah memiliki sumber daya yang memiliki kuaifikasi dibidang pengetahuan, keterampilan dan sikap.

Keterlibatan masyarakat dalam pengembangan objek wisata dalam hal perencanaan bentuknya berupa keikutsertaan dalam musyawarah 
desa dan sosialisasi. Dalam teori partisipasi termasuk dalam partisipasi interaktif. Dalam hal pelaksanaan terbagai menjadi sektor formal yang bentuknya berupa keikutsertaan dalam BINTEK dan pelatihan, namun belum menyentuh seluruh golongan masyarakat dan hanya terfokus pada kelompok.

\section{SARAN}

Berdasarkan hasil penelitian yang dilakukan penulis terkait potensi dan partisipasi masyarakat dalam pengembangan objek wisata di Desa Sambangan, adapun saran yang dapat diberikan agar kedepan perkembangan Desa Sambangan sebagai desa wisata semakin pesat yakni (a) Desa Sambangan mememiliki potensi wisata yang sangat beragam baik alam maupun buatan, sehingga sangat penting untuk mengembangkan kawasankawasan yang masih belum terjamah. Dalam upaya pengembangan hendaknya diperhatikan agar tidak terjadi eksploitasi alam secara berlebihan sehingga merusak fungsi aslinya. (b) Untuk mengembangkan potensi wisata yang ada, pastinya diperlukan partisipasi aktif masyarakat Desa Sambangan. Agar pariwisata dapat berjalan dengan baik. Peningkatan kualitas SDM tidak hanya berputar pada masyarakat yang tergabung dalam kelompok pariwisata namun menyentuh semua kalangan. (c) Selain poteni wisata yang sudah dikembangkan dan berjalan baik hingga saat ini, terdapat pula beberapa hal yang perlu dikembangkan sehingga berpotensi sebagai objek wisata buatan baru di Desa Sambangan, diantaranya adalah sanggar seni budaya dan retreat. Sanggar seni budaya rencana dibangun sebagai wadah menampung kreatifitas pemuda Desa Sambangan yang memiliki kemampuan dibidang seni tari, gamelan dan lain sebagainya. Diharapkan nantinya sanggar ini juga dapat menarik wisatawan untuk datang, karena memang selama ini desa sambangan belum menawarkan wisata budaya. Sedangakn untuk reatreat akan menyasar tamu yang menginginkan aktivitas wisata yang berbeda dari biasanya. Akan ditawarkan aktivitas seperti yoga, dan cooking class dengan metode memasak ala bali lengkap dengan bumbu-bumbunya. Dengan adanya objek wisata yang variatif, diharapkan kunjungan wisatawan ke Desa Wisata Sambangan dapat meningkat dari waktu ke waktu.

\section{DAFTAR RUJUKAN}

Adisasmitha, Rahardjo. 2006. Membangun Desa Partisipasif. Graha IImu: Yogyakarta

Maryani. $1997 . \quad K o n s e p$ Pengembangan Fasilitas Kawasan Wisata. Dalam http://repository.upi.edu/ope rator/upload/s mrl 0606842 chapter2.pdf Diakses tanggal 21 Januari 2020.

Nandi. 2008. Pariwisata dan Pengembangan Sumber Daya Manusia. Jurnal GEA Jurusan Pendidikan Geografi. Vol. 8 No. 1. 2534

Nuryanti, W. 1993. Desa Wisata. Concept, Perpective and Challenge. Yogyakarta: Gadjah Mada University Press

Oktami Dewi A. A. P. 2013. Partisipasi Masyarakat dalam Pengembangan Objek Wisata Bahari Di 
Jurnal Bosaparis: Pendidikan Kesejahteraan Keluarga

Volume 11, Nomor 2, Juli 2020

Pulau Kapoposang

Kabupaten Pangkajene dan

Kepulauan. Skripsi Fakultas

Ilmu Sosial dan IImu Politik,

Jurusan

Antropologi.Makassar

Universitas Hasanuddin.

Pitirin A, Sorokin. 1998. Social Stratification. New York : Harper.

Sudirtha, Gede, Ketut Widiartini, dan Made Suriani. 2019. Program Evaluation: Implementation of
Tourism Village Development. International Journal of Social Sciences and Humanities, Vol. 3 No. 3, December 2019, pages: $99 \sim 108$. Diakses Minggu, 12 Juli 2020 pukul 15:21 WITA

Sugiyono. 2011. Metode Penelitian

Kuantitatif, Kualitatif dan

$R \& D$. Bandung: Alfabeta 